\title{
Spatial, seasonal and ontogenetic changes in food resource use by a piscivore fish in two Pantanal lagoons, Brazil
}

\author{
Michele de Faveri Gimenes ${ }^{1}$, Rosemara Fugi ${ }^{1,2}$, Andréia Isaac ${ }^{1}$ and \\ Marlene Rodrigues da Silva ${ }^{1}$
}

\begin{abstract}
We evaluated the factors that affect the food resource use by Plagioscion ternetzi using three approaches: spatial, seasonal, and ontogenetic changes. Fish were sampled between March 2000 and February 2001 and March 2003 and February 2004 in the Sinhá Mariana and Chacororé lagoons, wetlands of the Pantanal Matogrossense. Fish was the predominant food in the diet, but shrimps and insects have been also consumed. The diet of $P$. ternetzi was significantly different between lagoons, but no difference was detected between dry and flood periods. In Sinhá Mariana lagoon, the diet mainly consisted of Psectrogaster curviventris, in both periods. In the flood period in Chacororé lagoon, fish was the dominant food (especially Astyanax spp., Leporinus spp. and Schizodon borellii), and in dry, shrimp and Eigenmannia spp. The Spearman coefficient indicated no correlation between the abundance of caught fish species and their abundances in the diet of $P$. ternetzi in Sinhá Mariana lagoon, and a strong negative correlation at Chacororé lagoon, although some very consumed preys were numerically abundant in the environment. Despite the intake of insect and shrimp, $P$. ternetzi was piscivorous since immature stages. A correlation between each item and the size classes of $P$. ternetzi was tested by means of Pearson correlation that showed that the changes in the use of resources over ontogenetic development have been represented by increased intake of $P$. curviventris in Mariana lagoon, and S. borellii at Chacororé lagoon, accompanying the increase in the size of the predator. In this way, the results suggest that several factors can be involved in the use of food resources by $P$. ternezi, among them the abundance, the size and morphological characteristics of the prey.
\end{abstract}

Neste estudo foram avaliados fatores que afetam o uso dos recursos alimentares por Plagioscion ternetzi, Boulenger, 1895, utilizando três abordagens: variações espacias, sazonais e ontogenéticas. Os peixes foram amostrados de fevereiro/2000 a março/2001 e de fevereiro/2003 a março/2004 nas lagoas Sinhá Mariana e Chacororé, Pantanal Matogrossense. Peixe foi o principal alimento, porém camarões e insetos também foram consumidos. A dieta de $P$. ternetzi foi significativamente diferente entre as lagoas, mas não diferiu entre os períodos de cheia e seca. Na lagoa Mariana, Psectrogaster curviventris foi a presa mais consumida em ambos os períodos. Na lagoa Chacororé, peixes dominaram a dieta (principalmente Astyanax spp., Leporinus spp. and Schizodon borellii) na cheia, e camarão e Eigenmannia spp. na seca. Uma correlação de Spearman mostrou que não existe correlação entre a abundância das espécies de peixes capturadas e suas abundâncias na dieta de P. ternetzi na lagoa Mariana, e que há uma correlação negativa na lagoa Chacororé, embora algumas presas importantes na dieta tenham sido numericamente importantes nas capturas. Embora tenha consumido camarões e insetos, $P$. ternetzi foi piscívora desde imatura. A correlação entre os itens alimentares e as classes de tamanho de $P$. ternetzi (Correlação de Pearson) evidenciou que as mudanças no uso do alimento durante a ontogenia estiveram associadas ao incremento no consumo de $P$. curviventris na lagoa Mariana, e de $S$. borellii na lagoa Chacororé, acompanhando o aumento de tamanho do predador. Assim, os resultados sugerem que vários fatores podem estar envolvidos no uso dos recursos alimentares por P. ternetzi, entre eles, a abundância, o tamanho e as características morfológicas das presas.

Key words: Chacororé lagoon, Diet, Plagioscion ternetzi, Sciaenidae, Sinhá Mariana lagoon.

\footnotetext{
${ }^{1}$ Universidade Estadual de Maringá, Programa de Pós-Graduação em Ecologia de Ambientes Aquáticos Continentais. Av. Colombo, 5790, 87020-900 Maringá, PR, Brazil.mfaveri@hotmail.com (MFG), andrisaac@yahoo.com.br (AI), marleners@ibest.com.br(MRS)

${ }^{2}$ Universidade Estadual de Maringá, Núcleo de Pesquisas em Limnologia, Ictiologia e Aquicultura. Av. Colombo, 5790, 87020-900 Maringá, PR, Brazil.rosemarafugi@gmail.com
} 


\section{Introduction}

The identification of mechanisms by which some species can become more important within their assemblages has based researches aimed at the conservation of species and ecosystems (Power et al., 1996; Creed, 2000). Predatory fish, for example, can affect their prey in several ways, altering the habitat use, density, period and intensity of foraging (Miyasaka et al., 2003; Petry et al., 2010), in addition to regulating their own abundance (Popova, 1978). Thus, piscivorous plays an important role in structuring and functioning of ecosystems (Almeida et al., 1997).

The diet of piscivorous fish is marked by seasonal, spatial and ontogenetic variations (Winemiller, 1989; Hahn et al., 1997; Bozza \& Hahn, 2010). The composition, abundance and availability of prey species affect the diet of predators (Cantanhêde et al., 2008, 2009; Meurer \& Zaniboni-Filho, 2012) as well predators can also exert strong control on prey community (Carpenter \& Kitchell, 1993). Although the availability of prey had been considered the primary factor in food intake by fish, other factors as type and size of the prey, place of refuge, and activity of predator and prey are also important for the item selection (Kahilainen \& Lehtonen, 2003; Cantanhêde et al., 2009). For some authors, among piscivorous fish, the size can be more important than the type of prey, because in aquatic environments the encounter rate between predator and prey and the success of capture are associated with the size of both (Juanes et al., 2002; Turesson et al., 2002; Specziár, 2011). Morphology characteristics of predator and prey others than body size can affect predator-prey interactions. For example, presence of spines on fins can protect the prey against predation, whereas shallow-bodied prey minimizes food handling time, and consequently, it is selected by predators (Turesson et al., 2002; Cantanhêde et al., 2009). However some fish predators select less active preys with spiny fin rays (Specziár, 2011). The gape size can influence the diet of piscivorous, limiting the prey size that can be consumed by a predator (Montaña et al., 2011). In this way, the piscivorous are the subject of several studies especially to assess the predation effect on populations of prey species (Nilsson, 1978).

The 'corvina' Plagioscion ternetzi Boulenger, 1895 was the most abundant piscivorous in the Chacororé and Sinhá Mariana lagoons (Cuiabá River basin, Mato Grosso State) throughout the study period, except for 'piranhas' Serrasalmus marginatus and Pygocentrus nattereri, which have a feeding strategy different from most piscivorous (Agostinho et al., 2003). Plagioscion ternetzi, Sciaenidae, endemic to South America, is a benthopelagic species with medium size not exceeding $39.0 \mathrm{~cm}$ of Standard Length (Casatti, 2005).

Considering the relevance for trophic ecology in identifying the factors that determine the diet of piscivorous, their importance as top predators in the control of food chains, and the important role played in the structuring and functioning of ecosystems, the goal of this study was to assess the factors that affect the food resource use by $P$. ternetzi using three approaches: spatial (two lagoons), seasonal (flood and dry period), and ontogenetic changes (size classes).

\section{Material and Methods}

The Chacororé and Sinhá Mariana lagoons are located in the complex of lagoons and wetlands of the Pantanal Matogrossense, Cuiabá River, Brazil (Fig. 1). The area of Cuiabá River basin has about $9,365 \mathrm{~km}^{2}$, covering the region of 'Cerrado' and Pantanal. The study area is in the lower stretch of Cuiabá River, where begins an extensive floodplain with a complex system of lagoons and floodable areas, making up the upper section of the Pantanal Matogrossense. The Chacororé lagoon has turbid waters, semicircular shaped, with $64.92 \mathrm{~km}^{2}$ in area, and $2.75 \mathrm{~m}$ in average depth (Pacheco \& Silva, 2009). During the flood season, it remains connected to Cuiabá River and Sinhá Mariana lagoon (Pacheco \& Silva, 2009). The Sinhá Mariana lagoon features black waters, presents an area of $11.25 \mathrm{~km}^{2}$, average depth of $3.58 \mathrm{~m}$, and is connected to Cuiabá River throughout the year (Pacheco \& Silva, 2009). Once it is a floodplain, periods of flood and dry are remarkable in this region. The flood period occurs between November and April, and the dry period between May and October (Novakowski et al., 2008).

Fish were sampled monthly from March 2000 to February 2001 and from March 2003 to February 2004 with 14 gill nets (10 m length each) with different mesh sizes (2.4 to $30.0 \mathrm{~cm}$ ), exposed for 24 hours with inspections at 8,16 and 22 hours. The littoral regions were sampled with seining nets $(20 \mathrm{~m}$ length, $1 \mathrm{~cm}$-mesh size) during the day and at night. Fishes were identified, counted, measured and weighed. The stomachs were removed and fixed in formaldehyde $4 \%$. Voucher specimens of Plagioscion ternetzi were deposited in the Fish Collection of the Núcleo de Pesquisas em Limnologia, Ictiologia e Aquicultura (Nupélia) of the Universidade Estadual de Maringá (NUP3006).

The stomach content of 129 individuals of $P$. ternetzi was examined, and the food items were identified to the lowest possible taxonomic level (McCafferty, 1981; Britski et al., 2007). The volume of each item was obtained by the displacement of the water column - volumetric method (Hyslop, 1980), using a set of graduated cylinders.

In order to verify ontogenetic variations, the individuals were arbitrarily grouped into five size classes according to the variation in standard length: class $1=1.5-7.5 \mathrm{~cm}$; class $2=7.6-13.6 \mathrm{~cm}$; class $3=13.7-19.7 \mathrm{~cm}$; class $4=19.8-25.8 \mathrm{~cm}$; class $5=25.9-34.5 \mathrm{~cm}$.

The differences in the diet of $P$. ternetzi between lagoons and periods, and among the size classes, were tested by the multi-response permutation procedure (MRPP) (Zimmerman 

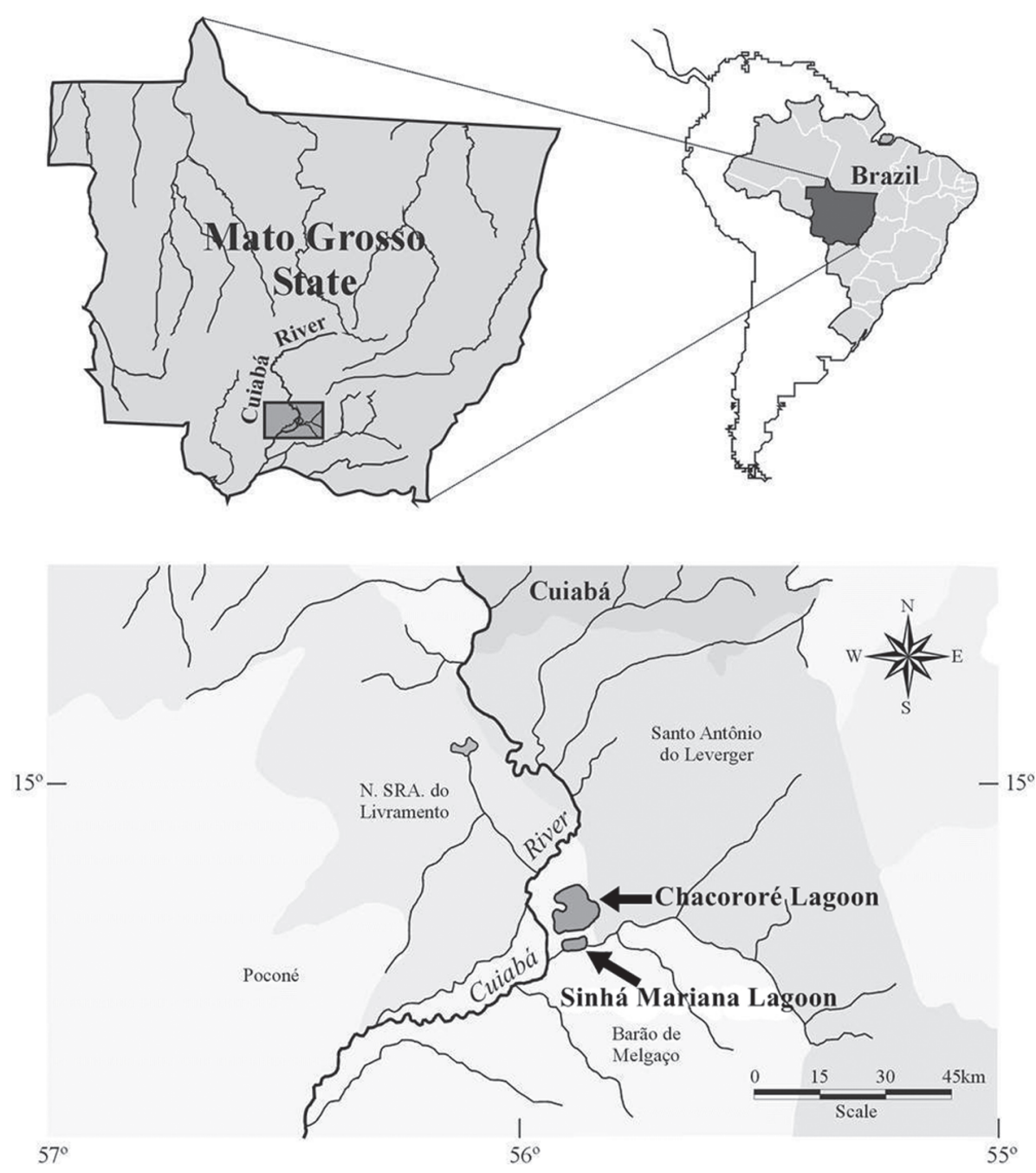

Fig. 1. Location of the study area in the system of Chacororé-Sinhá and Mariana lagoons, Pantanal Matogrossense, Mato Grosso State, Brazil.

et al., 1985), with the data of volume of food items. The significance of the null hypothesis (the diet does not differ between lagoons, periods and size classes) was checked by the Monte Carlo randomization procedure with 10,000 permutations. The analyses were run using the software PC-Ord ${ }^{\circledR} 4.0$ (McCune \& Mefford, 1999).

A Pearson correlation analysis was used to verify correlation between the abundance of each item in the diet and the size classes of $P$. ternetzi. The abundance of fish species in the sampled environments was correlated by lagoon and period with the abundance of fish species consumed by $P$. ternetzi, with the purpose to verify if the most consumed fish were also the most abundant in the lagoons. For this, it was employed the Spearman correlation. These analyzes were performed with the software BioEstat 5.0 (Ayres et al., 2007), and the adopted significance level was $p<0.05$. Species-abundance curves of the fish fauna from the sampled environments were plotted per lagoon and period to visualize the results.

\section{Results}

Fish was the dominant food in the diet of Plagioscion ternetzi, in addition to shrimp and insect. The preys that could not have been identified due to the high degree of digestion were grouped into 'fish remains', and those that occurred at volume lower than $1 \%$ of diet were grouped into 'other fish'. In Sinhá Mariana lagoon the species grouped into 'other fish' were Odontostilbe pequira, Loricariichthys spp., Gymnotus spp., Moenkhausia spp., Plagioscion ternetzi, Corydoras spp., and Pachyurus bonariensis. The species grouped into 'other fish' in Chacororé lagoon were P. ternetzi, Aphyocharax spp., P. bonariensis, Pellona flavipinnis, and Psectrogaster curviventris. A significant difference in the diet of $P$. ternetzi was registered between the Sinhá Mariana and Chacororé lagoons $(\mathrm{A}=0.049, \mathrm{p}<$ 0.001).

Plagioscion ternetzi consumed 15 fish species in Sinhá Mariana lagoon besides a small volume of shrimp. During 
the flood period, the dominant prey was P. curviventris (63.4\%), followed by Curimatella dorsalis $(11.3 \%)$ and Eigenmannia spp. (10.8\%). During the dry period, no item was dominant, since three fish preys have been consumed at similar volume: $P$. curviventris (28.8\%), Tetragonopterus argenteus (28.8\%) and Eigenmannia spp. (22.3\%) (Fig. 2a). In this lagoon, the diet was not significantly different between the periods $(\mathrm{A}=-0.0003, \mathrm{p}=0.37)$.

In Chacororé lagoon, P. ternetzi consumed 14 fish species, insect and a large volume of shrimp. During the flood, stood out Astyanax spp. (17.8\%), Leporinus spp. (16.5\%) and Schizodon borellii (16.1\%) (Fig. 2b). In the dry period, the main prey was shrimp (40\%), followed by Eigenmannia spp. (23.3\%) (Fig. 2b). However, no significant difference was detected between studied periods $(\mathrm{A}=0.007$, $\mathrm{p}=0.089$ ).

According to MRPP, significant alterations were observed in the diet of $P$. ternetzi throughout ontogenetic development in both lagoons (Sinhá Mariana: $\mathrm{A}=0.086, \mathrm{p}=$ 0.0058; Chacororé: $\mathrm{A}=0.056, \mathrm{p}=0.0005$ ). In Sinhá Mariana, although fish had been the most consumed item for all size classes, there was an alteration in the kind of prey (Fig. 3a). The smaller individuals, belonging to classes 1 and 2, have predominantly fed on Eigenmannia spp. (100\% and 60\%, respectively) whose individuals were young not exceeding $7.5 \mathrm{~cm}$. In the class 3 individuals fed mainly on Pimelodella spp. (43\%). Psectrogaster curviventris was the most consumed prey by $P$. ternetzi individuals of the classes 4 $(47.2 \%)$ and $5(59.6 \%)$, although the diet in these classes had been more diversified. According to Pearson correlation, $P$. curviventris was positively related with size classes $(\mathrm{r}=$ $0.942, \mathrm{p}=0.016$ ), evidencing its increased volume in the diet of $P$. ternetzi along its growth. In Chacororé, individuals of all sizes have consumed fish at different proportions. In the classes 1, 2, and 3, young individuals of Loricariichthys spp. (51.0\%), Roeboides spp. (37.2\%), and shrimp (48.4\%) were, respectively, the most consumed items. In order of importance, insect was the second most consumed item by these size classes $(38.3 \%, 24.4 \%$ and $35.5 \%$, respectively) (Fig. 3b). The diet of individuals of classes 4 and 5 had been more diversified, and shrimp (32.4\%) and Astyanax spp. (27.9\%) were, respectively, the most consumed items. The Pearson correlation pointed out a significant positive correlation $(\mathrm{r}=0.888, \mathrm{p}=0.044)$ between the presence of $S$. borellii in the diet and the size classes of $P$. ternetzi, and it was observed an increased abundance of this item from the class 4 .

The fish species richness in both lagoons was high, with 127 species in Sinhá Mariana during the flood, and 122 in the dry; and 136 species in Chacororé lagoon in the flood, and 132 in the dry period. For most species, a low abundance was observed in both lagoons (Fig. 4). In the comparison of the rank of species caught in Sinhá Mariana with those consumed by $P$. ternetzi, the Spearman correlation evidenced no correlation between the abundance of captured species
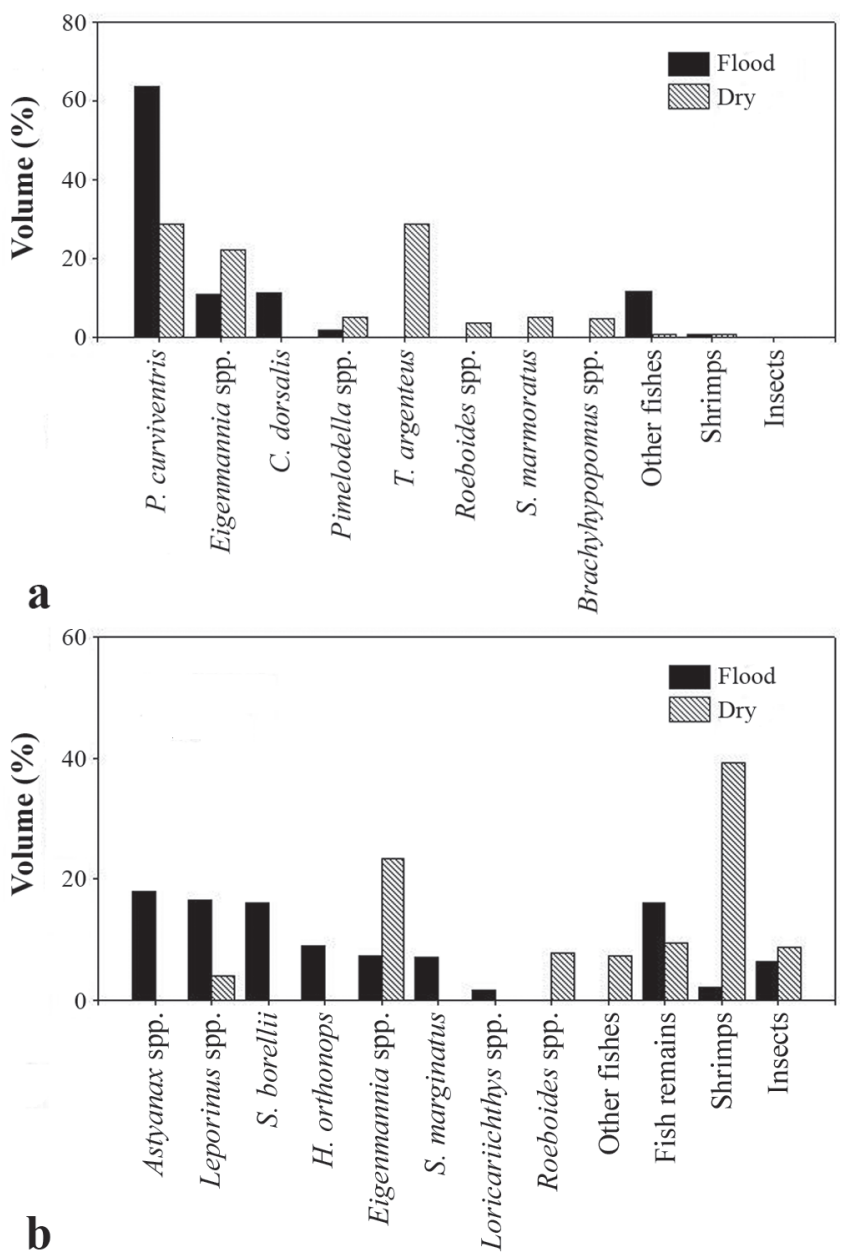

Fig. 2. Diet composition of Plagioscion ternetzi in the lagoons Sinhá Mariana (a) and Chacororé (b), during the flood and dry periods.

and their abundances in the diet (flood: $\mathrm{rs}=1.05, \mathrm{p}=0.23$; dry: $\mathrm{rs}=0.11, \mathrm{p}=0.19$ ). Psectrogaster curviventris, the most consumed species $(63.4 \%)$ during the flood, was the tenth species most abundant in the environment (Fig. 4a). The two fish species most consumed during the dry period, $P$. curviventris and $T$. argenteus, presented different abundances in the environment. While the first species was the tenth most abundant, the latter species was the $33^{\text {th }}$ in number of individuals (Fig. 4b). Eigenmannia spp. also represented an important part of the diet of $P$. ternetzi during the dry period, and was found at very low abundance in the environment, being the $75^{\text {th }}$ most abundant species (Fig. $4 \mathrm{~b}$ ).

In Chacororé, the Spearman correlation showed a strong negative correlation between the abundance of caught fish species and their abundances in the diet of $P$. ternetzi (flood: rs $=-0.38, \mathrm{p}=0.01 ;$ dry: $\mathrm{rs}=-0.59, \mathrm{p}=0.003)$. The diet of $P$. ternetzi during the flood period was not dominated by a single prey fish, and the three most consumed prey, Astyanax spp. (17.8\%), S. borellii (16.1\%) and Leporinus spp. (16.5\%), were not among the most abundant in the environment $\left(37^{\text {th }}\right.$, 


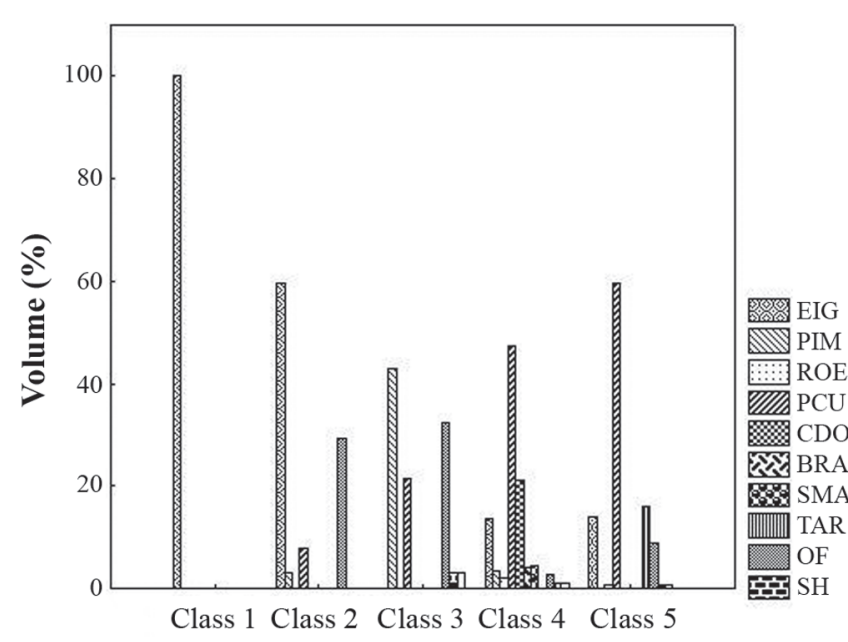

a

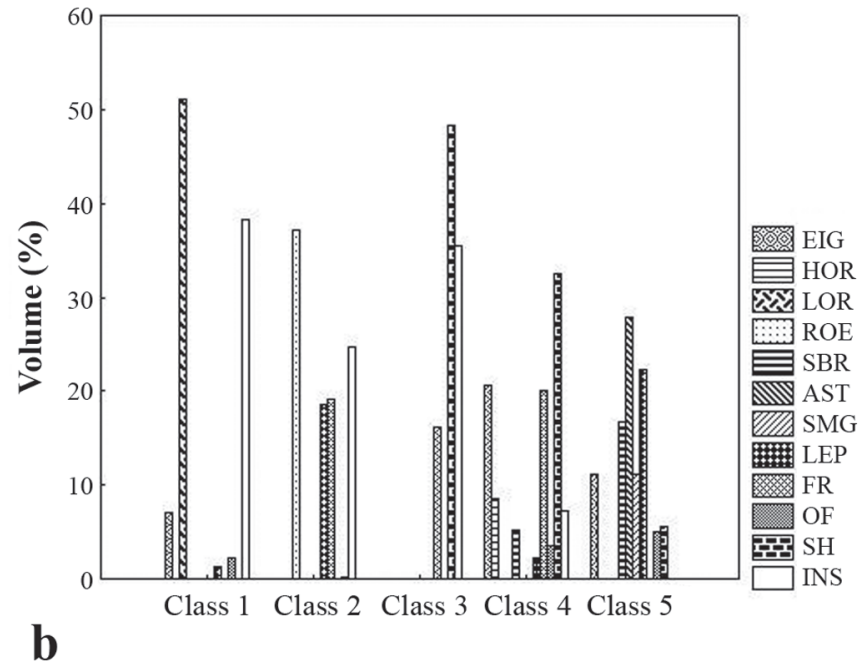

Fig. 3. Diet composition of Plagioscion ternetzi by size class in Sinhá Mariana lagoon (a) and in Chacororé lagoon (b) (EIG: Eigenmannia spp.; PIM: Pimelodella spp.; ROE: Roeboides spp.; PCU: Psectrogaster curviventris; CDO: Curimatella dorsalis; BRA: Brachyhypopomus spp.; SMA: Synbranchus marmoratus; TAR: Tetragonopterus argenteus; HOR: Hemiodus orthonops; LOR: Loricariichthys spp.; SBR: Schizodon borellii; AST: Astyanax spp.; SMG: Serrasalmus marginatus; LEP: Leporinus spp.; OF: other fish; SH: shrimp; INS: insect; FR: fish remains).

$30^{\text {th }}$ and $25^{\text {th }}$, respectively, in number of caught individuals) (Fig. 4c). During the dry period, when the shrimp represented a considerable part in volume of the $\operatorname{diet}(40 \%)$, the only fish prey important was Eigenmannia spp. (23\%), being the $13^{\text {th }}$ most abundant in the environment (Fig. 4d).

\section{Discussion}

Plagioscion ternetzi has consumed several fish species, shrimp and insect at different proportions, result of spatial, temporal and ontogenetic variations in the diet. The use of these resources was also recorded for its congener Plagioscion squamosissimus, in different environments. In the upper Paraná River floodplain, fish was the main food for P. squamosissimus, and shrimp complemented its diet (Hahn et al., 1997), whereas in Amazon region, shrimp dominated the diet of this species, and fish was a secondary food (Goulding \& Ferreira, 1984). The wide food spectrum of $P$. ternetzi represented the pattern commonly verified for piscivorous species (Almeida et al., 1997; L'abeé-Lund, 2002; Hahn et al., 1997; Cantanhêde et al., 2008), however, corroborating Popova (1978), the basic part of the diet of $P$. ternetzi has included few species.

The prey consumed by P. ternetzi has been different for both lagoons. The spatial variations in the diet may be partially associated with the presence and abundance of prey in the studied environments. In Sinhá Mariana lagoon the most consumed prey, P. curviventris, occupied the tenth position in number of caught individuals in both periods, whereas in Chacororé lagoon this prey presents volume lower than $1 \%$ of the diet and was less abundant than in Sinhá Mariana lagoon, occupying the $48^{\text {th }}$ and $43^{\text {th }}$ position in number of individual in flood and dry periods, respectively. Similarly, data of shrimp catches (Acetes paraguayensis) in these two lagoons showed that of the total captured in number of individuals, $62 \%$ were registered in Chacororé lagoon, and $38 \%$ in Sinhá Mariana lagoon (A. Bialetzki, pers. comm.), explaining the higher consumption of this prey in the former environment.

Although the prey abundance is considered a determinant factor in the exploitation of food resources by predatory fish (Griffiths, 1975; Popova, 1978; Cantanhêde et al., 2009), the lack of correlation between the prey abundances in the environment and in the diet of P. ternetzi in Sinhá Mariana lagoon, and the strong negative correlation in Chacororé lagoon, indicate that the prey abundance was not the major factor involved in the use of food resource by $P$. ternetzi. However, in Sinhá Mariana lagoon P. curviventris, the most consumed prey, was numerically very abundant, thus, the high consumption can be associated with the abundance of this prey in the environment, but we cannot disregard other factors, since other fish species more abundant than $P$. curviventris were little or not consumed. Among them, some present morphological characteristics to prevent predation, as is the case of Trachydoras paraguayensis, Auchenipterus osteomystax, and Pimelodella gracilis that have spines on dorsal and pectoral fins, which protect against predation. Nevertheless, besides these species, other more abundant than $P$. curviventris and without apparent morphological constraint were not consumed, indicating that other features restrict their predation, such as the use of different 

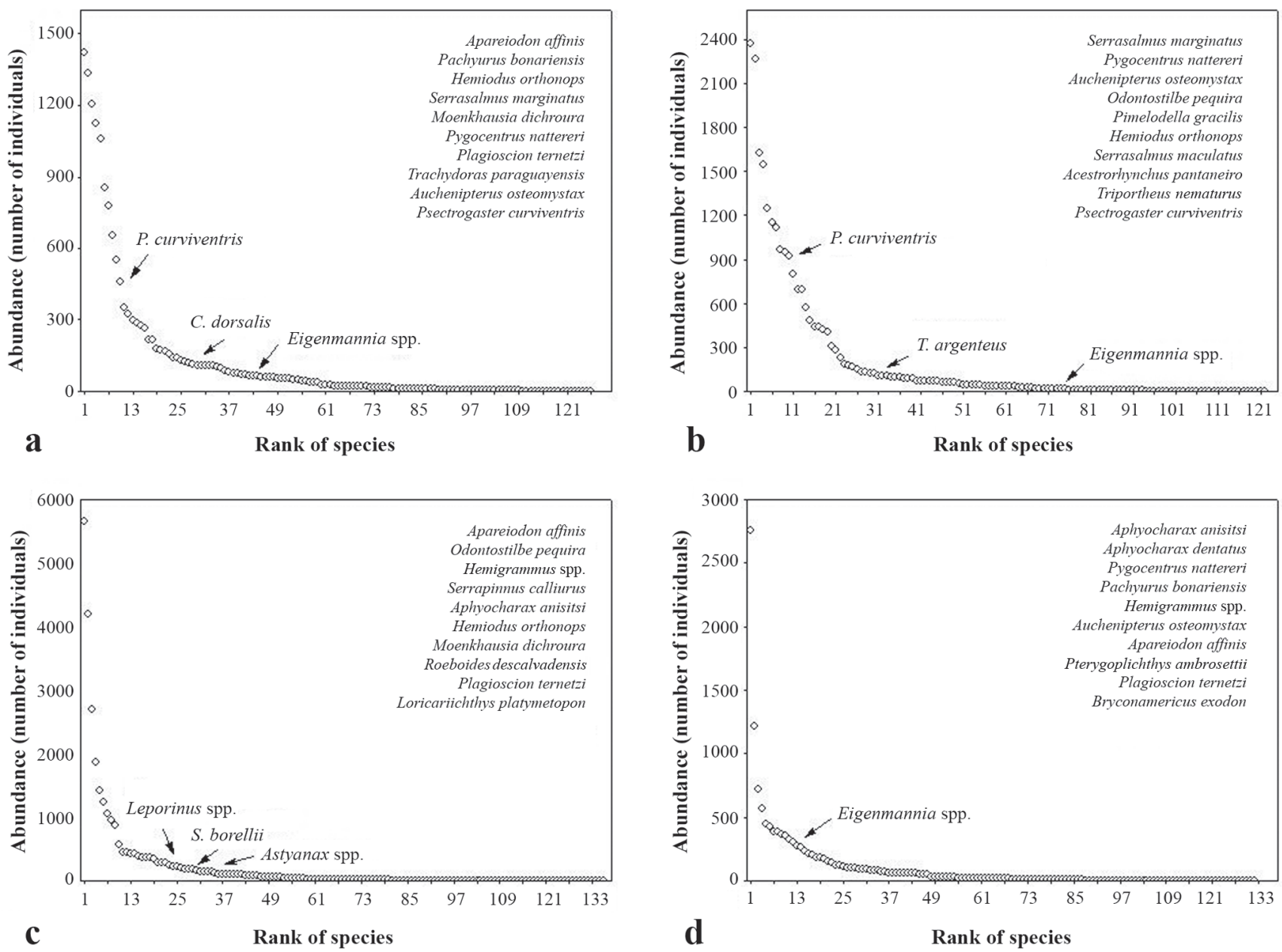

Fig. 4. Species abundance curve of fish species at Sinhá Mariana lagoon $(\mathbf{a}=$ flood period and $\mathbf{b}=$ dry period $)$ and Chacororé lagoon $(\mathbf{c}=$ flood period and $\mathbf{d}=$ dry period $)$. Species within the rectangle correspond to the ten most abundant in the lagoon, in order of importance; the species out of the rectangle correspond to the most consumed by Plagioscion ternetzi.

microhabitats or prey activity (Specziár, 2011), which can reduce the rate of encounter between predator and prey. On the other hand, Eigenmannia spp., a prey widely consumed by $P$. ternetzi, had a very low abundance in the environment, suggesting some preference for this species, which can be associated to its slender body shape, which eases its consumption and can reduce the handling time and maximize energy gain (Juanes, 1994). Wooton (1990) suggests that the diet of fish is a result of the interaction between the availability of prey in the environments and the preference of each species for certain food items, what can explain the diet of P. ternetzi.

Remarkable, but not significant, temporal variations in the $\operatorname{diet}$ of $P$. ternetzi were verified in Chacororé lagoon. During the high water period, when this lagoon connects with the Cuiabá River and Sinhá Mariana lagoon, several species of fish predominated in the diet of $P$. ternetzi. During the dry period, although fish have represented the greater part of the diet, $40 \%$ was made up of shrimp. According to Winemiller \& Jepsen
(1998), the natural dryness of tropical floodplains increases fish density (per surface unit) and intensify species interactions because of declines in food resources. Thus, during this period some species of fish leave under limiting conditions typical of these isolated pools where they compete for scarce resources and experience high predation risk and poor water quality (Winemiller \& Jepsen, 1998). The expressive consume of shrimp only in the dry period can be result of intense biotic interactions, especially between predator and prey, occurring in this period (Winemiller \& Kelso-Winemiller, 2003), which may have led $P$. ternetzi to use an available and less used food by other piscivorous in Chacororé lagoon (Corrêa et al., 2011).

Moreover, although it had consumed insect and shrimp, $P$. ternetzi was piscivorous since immature stages in both studied lagoons. The observed changes in the use of resources throughout the ontogenetic development were represented by increased consumption of some prey species, accompanying the increase in size of the predator. In both lagoons, it was 
observed the same trend, i.e., the consumption of smaller items like insect and young fish by smaller individuals, and as the predator grows, it starts consuming larger prey, such as shrimp and larger fish. Body size can be considered a predictor of the maximum potential prey size that a predator can consume (Montaña et al., 2011). This trend has been verified to other piscivorous (Winemiller, 1989; Hahn et al., 1997; Bozza \& Hahn, 2010) and can be related to morphological development (Wooton, 1990) or the occupation of different habitats (LoweMcConnell, 1975). Larger individuals presented a more diversified diet, result of the development of morphological characteristics that allow the use of new habitats (Galarowicz et al., 2006), and the possibility to handle different types of food (Hyndes et al., 1997).

In this study, the great diversity of potential prey species for Plagioscion ternetzi was reflected in the number of species present in the predator's diet, but the prey abundance was not the major factor for the diet of the studied species, although some preys very consumed were numerically abundant in the environment. In this way, the results suggest that several factors can be involved in the use of food resources by P. ternezi, among them the abundance, the size and morphological characteristics of the prey.

\section{Acknowledgments}

We thank the Núcleo de Pesquisas em Limnologia, Ictiologia e Aquicultura (Nupélia) for financial and infrastructure. M. F. Gimenes, A. Isaac and M. R. Silva acknowledge the CAPES for providing grants.

\section{Literature Cited}

Agostinho, C. S., N. S. Hahn \& E. E. Marques. 2003. Patterns of food resource use by two congeneric species of piranhas (Serrasalmus) on the upper Paraná River floodplain. Brazilian Journal of Biology, 63: 177-182.

Almeida, V. L. L., N. S. Hahn \& A. E. A. M. Vazzoler. 1997. Feeding patterns in five predatory fishes of the high Paraná River floodplain (PR, Brazil). Ecology of Freshwater Fish, 6: 123-133.

Ayres, M., M. Ayres Jr., D. L. Ayres \& A. A. S. Santos. 2007. BioEstat: aplicações estatísticas nas áreas das ciências bio-médicas. Sociedade Civil Mamirauá, MCT - CNPq, Belém, Pará, Brasil.

Bozza, A. N. \& N. S. Hahn. 2010. Uso de recursos alimentares por peixes imaturos e adultos de espécies piscívoras em uma planície de inundação neotropical. Biota Neotropica, 10: 217-226.

Britski, H. A., K. Z. de S., Silimon \& B. S. Lopes. 2007. Peixes do Pantanal: Manual de Identificação. Brasília, Embrapa Informação Tecnológica, 227p.

Cantanhêde, G., N. S. Hahn, R. Fugi \& E. A. Gubiani. 2008. Alterations on piscivorous diet following change in abundance of prey after impoundment in a Neotropical river. Neotropical Ichthyology, 6: 631-636.

Cantanhêde, G., R. Fugi \& N. S. Hahn. 2009. Variation in prey selection of a piscivorous fish after the impoundment of a neotropical reservoir: prey size and type. Journal of Fish Biology, 75: 76-86.

Carpenter, S. R. \& J. F. Kitchell. 1993. The Trophic Cascade in Lagoons. New York, Cambridge University Press, 385p.

Casatti, L. 2005. Revision of the South American freshwater genus Plagioscion (Teleostei, Perciformes, Sciaenidae). Zootaxa, 1080: 39-64.

Corrêa, C. E., M. P. Albrecht \& N. S. Hahn. 2011. Patterns of niche breadth and feeding overlap of the fish fauna in the seasonal Brazilian Pantanal, Cuiabá River basin. Neotropical Ichthyology, 9: 637-646.

Creed, R. P. Jr. 2000. Is there a new keystone species in North American lagoons and rivers? Oikos, 91: 405-408.

Galarowicz, T. J., J. A. Adams \& D. H. Wahl. 2006. The influence of prey availability on ontogenetic diet shifts of a juvenile piscivore. Canadian Journal of Fisheries and Aquatic Sciences, 63: 1722-1733.

Goulding, M. \& E. J. G. Ferreira. 1984. Shrimp-eating fishes and a case of prey-switching in Amazon Rivers. Revista Brasileira de Zoologia, 2: 85-97.

Griffiths, D. 1975. Prey availability and food of predators. Ecology, 56: 1209-1214.

Hahn, N. S., A. A. Agostinho \& R. Goitein. 1997. Feeding ecology of curvina Plagioscion squamosissimus (Hechel, 1840) (Osteichthyes, Perciformes) in the Itaipu Reservoir and Porto Rico Floodplain. Acta Limnologica Brasiliensia, 9: 11-22.

Hyndes, G. A., M. E. Platell \& I. C. Potter. 1997. Relationships between diet and body size, mouth morphology, habitat and movements of six sillaginid species in coastal Waters: implications for resource partitioning. Marine Biology, 28: 585-598.

Hyslop, E. J. 1980. Stomach contents analysis, a review of methods and their application. Journal of Fish Biology, 17: 411-429.

Juanes, F. 1994. What determines prey size selectivity in piscivorous fishes? Pp. 79-100. In: Stouder, D. J., K. L. Fresh \& R. J. Feller (Eds.). Theory and Application in Fish Feeding Ecology. Columbia, University South Carolina Press, 390p.

Juanes, F., J. A. Buckel \& F. S. Scharf. 2002. Feeding ecology of piscivorous fishes. Pp. 267-284. In: Hart, P. J. B. \& J. D. Reynolds (Eds.). Handbook of fish biology and fisheries. Volume 1. Oxford, Blackwell Publishing, 413p.

Kahilainen, K. \& H. Lehtonen. 2003. Piscivory and prey selection of four predator species in a whitefish dominated subartic lagoon. Journal of Fish Biology, 63: 659-672.

L'abeé-Lund, J. H., P. Aass \& H. Sægrov. 2002. Long-term variation in piscivory in a brown trout population: effects of changes in available prey organisms. Ecology of Freshwater Fish, 11: 260269.

Lowe-McConnell, R. H. 1975. Fish communities in tropical freshwaters: their distribution, ecology and evolution. London, Longman, 337p.

Meurer, S. \& E. Zaniboni-Filho. 2012. Reproductive and feeding biology of Acestrorhynchus pantaneiro Menezes, 1992 (Osteichthyes: Acestrorhynchidae) in areas under the influence of dams in the upper Uruguay River, Brazil. Neotropical Ichthyology, 10: 159-166.

McCafferty, W. P. 1981. Aquatic Entomology: the fisherman's and ecologist's illustraded guide to insects and their relatives. Boston, Science Books International, 448p.

McCune, B. \& M. J. Mefford. 1999. PC-ORD: multivariate analysis of ecological data. Version 4.27 edition. MjM Software Design, Gleneden Beach. 
Miyasaka, H., M. Genkai-Kato, N. Kuhara \& S. Nakano. 2003. Predatory fish impact on competition between stream insect grazers: a consideration of behaviorally- and density-mediated effects on an apparent coexistence pattern. Oikos, 101: 511-520.

Montaña, C. G., C. A. Layman \& K. O. Winemiller. 2011. Gape size influences seasonal patterns of piscivore diets in three Neotropical rivers. Neotropical Ichthyology, 9: 647-655.

Nilsson, N. A. 1978. The role of size-biased predation in competition and interactive segregation in fish. Pp. 303-325. In: Gerking, S. D. (Ed.). Ecology of freshwater fish production. Oxford, Blackwell Scientific, 520p.

Novakowski, G. C., N. S. Hahn \& R. Fugi. 2008. Diet seasonality and food overlap of the fish assemblage in a pantanal pond. Neotropical Ichthyology, 6: 567-576.

Pacheco, E. B. \& C. J. Silva. 2009. Fish associated with aquatic macrophytes in the Chacororé-Sinhá Mariana Lagoon system and Mutum River, Pantanal of Mato Grosso, Brazil. Brazilian Journal of Biology, 69: 101-108.

Petry, A. C., L. C. Gomes, P. A. Piana \& A. A. Agostinho. 2010. The role of the predatory trahira (Pisces: Erythrinidae) in structuring fish assemblages in lagoons of a Neotropical floodplain. Hydrobiologia, 651: 115-126.

Popova, O. A. 1978. The role of predaceous fish in ecosystems. Pp. 215-249. In: Gerking, S. D. (Ed.). Ecology of freshwater fish production. Oxford, Blackell Scientific, 520p.

Power, M. E., M. S. Parker \& J. T. Wootton. 1996. Disturbance and food chain length in rivers. Pp. 286-297. In: Polis, G. A. \& K. O. Winemiller (Eds.). Food Webs: Integration of Patterns \& Dynamics. New York, Chapman \& Hall, 472p.

Specziár, A. 2011. Size-dependent prey selection in piscivorous pikeperch Sander lucioperca and Volga pikeperch Sander volgensis shaped by bimodal prey distribution. Journal of Fish Biology, 79: 1895-1917.

Turesson, H., A. Persson \& C. Bronmark. 2002. Prey size selection in piscivorous pikeperch (Stizostedion lucioperca) includes active prey choice. Ecology of Freshwater Fish, 11: 223-233.

Winemiller, K. O. \& L. C. Kelso-Winemiller. 2003. Food habitats of tilapinae cichlids of the Upper Zambezi River and floodplains during the descending phase of the hydrological cycle. Journal of Fish Biology, 63: 120-128.

Winemiller, K. O. 1989. Ontogenetic diet shifts and resource partitioning among piscivorous fishes in the Venezuelan llanos. Environmental Biology of Fishes, 26: 177-199.

Winemiller, K. O. \& D. B. Jepsen. 1998. Effects of seasonality and fish movement on tropical river food webs. Journal of Fish Biology, 3: 267-296.

Wooton, R. J. 1990. Ecology of teleost fishes. London, Chapman \& Hall, 404p.

Zimmerman, G. M., H. Goetz \& P. W. Mielke. 1985. Use of an improved statistical method for group comparisons to study effects of prairie fire. Ecology, 66: 606-611.

Submitted March 7, 2012

Accepted October 19, 2012 by Lilian Casatti

Published March 31, 2013 